\title{
Kepemimpinan Yesus Sebagai Acuan Bagi Kepemimpinan Gereja Masa Kini
}

\section{Jesus' Leadership as a Reference for Today's Church Leadership}

\author{
Yahya Wijaya ${ }^{1 *}$
}

${ }^{1)}$ Fakultas Teologi Universitas Kristen Duta Wacana, Indonesia

*Penulis korespondensi:yahyawijaya@staff.ukdw.ac.id

Received: 23 March 2018/Revised: 9 May 2018 /Accepted: 23 July 2018

\begin{abstract}
Abstrak
Artikel ini membandingkan antara model kepemimpinan Yesus dengan modelmodel kepemimpinan para penguasa formal di zamannya. Berakar pada hubungan spiritual yang mendalam dengan Bapanya, dan digerakkan oleh hati yang berbelaskasihan, kepemimpinan Yesus menantang praktik-praktik kepemimpinan gereja di Indonesia masa kini yang ditandai oleh sentralisasi institusional, otonomi lokal yang absolut, atau tradisionalisme.

Kata-kata kunci: etika kepemimpinan, teologi Kerajaan Allah, kepemimpinan pelayan, Pontius Pilatus, Herodes, Kayafas.

Abstract

This article compares the leadership model of Jesus with those of the formal prominent leaders in his time. Rooted in a deep spiritual relationship with his Father, and moved by a compassionate heart, Jesus' leadership challenges today's church leadership practices in Indonesia which is marked by either institutional centralization, absolute local autonomy, or traditionalism.
\end{abstract}

Key words: leadership ethics, theology of the Kingdom of God, servant leadership, Pontius Pilate, Herod, Caiaphas.

\section{Pendahuluan}

Larisnya buku-buku tentang kepemimpinan dan program-program pengembangan kepemimpinan sejak beberapa tahun yang lalu menandakan bangkitnya minat terhadap kepemimpinan baik di kalangan bisnis dan politik maupun di ranah masyarakat sipil dan organisasi-organisasi sosial. Kepemimpinan juga menjadi subjek kajian dalam berbagai disiplin yang berbeda, termasuk psikologi, sosiologi, politik, dan ilmu manajemen. Semua itu menghasilkan konsep-konsep kepemimpinan yang sangat beragam. Salah satu pemicu kesadaran tentang perlunya mempelajari kepemimpinan secara lebih konseptual adalah dirasakannya gejala-gejala 
krisis kepemimpinan. ${ }^{1}$ Gejala-gejala itu antara lain tidak berjalannya sistem suksesi kepemimpinan karena ketergantungan yang terlalu besar terhadap pemimpin lama yang sudah habis masa baktinya. Akibatnya, nepotisme dan favoritisme menjadi tidak terhindarkan dan menimbulkan ketidakpuasan pihak-pihak yang menghendaki sistem yang lebih fair dan transformatif. Selain itu dapat disebutkan juga tentang seringnya terjadi konflik dalam proses pergantian kepemimpinan karena permainan politik kekuasaan dan manipulasi sentimen massa pendukung. Kepemimpinan dalam komunitas dan lembaga keagamaan tidak kebal terhadap krisis, bahkan dapat dibilang termasuk yang paling rawan mengalami krisis semacam itu. Sebabnya adalah karena agama mengandung unsur-unsur yang mudah dimainkan untuk menggalang dukungan atau penolakan terhadap kepemimpinan seseorang. ${ }^{2}$ Misalnya, ayat-ayat Kitab Suci dapat dikutip dan ditafsirkan sedemikian rupa untuk membenarkan atau menolak pencalonan seseorang karena paham teologis, gender, atau status pernikahannya. Contoh lain, model kepemimpinan paternalistik yang merupakan bagian dari sejarah banyak komunitas keagamaan sering dipakai sebagai acuan untuk menolak sistem kepemimpinan masa kini yang cenderung lebih demokratis dan meritokratis.

Kepemimpinan tidak termasuk dalam struktur kurikulum pendidikan teologi konvensional yang memersiapkan calon-calon rohaniwan lebih sebagai pengajar dan perawat umat. Meskipun isu kepemimpinan disinggung dalam beberapa mata kuliah tertentu seperti Manajemen Gereja atau Pembangunan Jemaat, kepemimpinan sebagai suatu konsep yang utuh dan bersifat teologis tampaknya tidak cukup terwadahi. Upaya-upaya para pegiat dan pemimpin gereja untuk mempelajari kepemimpinan seringkali lebih berupa penerapan dari teoriteori kepemimpinan sekular yang didesain untuk kalangan bisnis atau pemerintahan. Teori-teori itu sendiri sangat beragam dan bersumber pada pemikiran filosofis yang berbeda-beda bahkan beberapa di antaranya berlawanan. ${ }^{3}$ Meskipun relevansi teori-teori itu bagi konteks gereja tidak perlu dipersoalkan di sini, gereja memiliki sumber konseptualnya sendiri yang masih layak untuk dimanfaatkan sebelum meminjam konsep yang aslinya ditujukan bagi konteks yang lain. Agar konsisten dengan pengaku-

${ }^{1}$ Sandu Frunza, "Ethical Leadership, Religion and Personal Development in the Context of Global Crisis," Journal for the Study of Religions and Ideologies 16, no. 46 (2017): 4.

2 Zubaedi, "The Use of Religious Issues in Local Head Election (Pilkada): A Lesson from Bengkulu," in Filsafat, Etika, Dan Kearifan Lokal Untuk Konstruksi Moral Kebangsaan, ed. Siti Syamsiatun and Nihayatul Wafiroh (Geneva: Globethics.net, 2013), 187-205.

${ }^{3}$ Douglas A. Hicks, "Ethical Diversity and the Leader's Religious Commitments," in The Quest for Moral Leaders: Essays on Leadership Ethics, ed. Joanne B. Ciulla (Cheltenham: Edward Elgar Pub, 2005). 
an dan keyakinan dasar gereja, kepemimpinan gereja dan lembagalembaga gerejawi tidak bisa tidak terhubung pada narasi kepemimpinan Yesus Kristus sebagai tokoh sentral gereja. Tulisan ini merupakan upaya untuk menggali konsep kepemimpinan berdasarkan narasi Injil tentang kepemimpinan Yesus Kristus.

\section{Metode}

Kajian ini menggunakan metode etika kristologis dalam kaitan dengan teologi praktis. Dalam metode ini, pribadi dan perilaku Yesus Kristus sebagaimana dipersaksikan dalam sumber-sumber teologis dijadikan gambaran ideal bagi pembentukan karakter, dan inspirasi bagi pengembangan moralitas masa kini. ${ }^{4}$ Pengenalan terhadap Yesus Kristus di sini ditujukan kepada eksistensinya sebagai manusia yang konkret, bukan pertama-tama pada dimensi keilahiannya seperti dirumuskan dalam kredo-kredo gereja. Etika kristologis tidak bertujuan menghasilkan tiruan-tiruan Yesus di masa kini. Etika kristologis juga bukan sekadar mengajarkan ulang ajaran-ajaran Yesus. Yang diharapkan adalah karakter dan perilaku Yesus Kristus berpengaruh secara signifikan pada sikap moral orang-orang yang percaya dan mengikutnya. Tulisan ini membatasi kajian tentang pribadi dan perilaku Yesus Kristus pada aspek kepemimpinannya. Sumber yang digunakan adalah kitab-kitab Injil dalam Alkitab yang dipahami sebagai suatu kesatuan yang saling melengkapi. Kaitan dengan teologi praktis dibatasi pada masalah kepemimpinan gerejawi dan implikasinya bagi kepemimpinan secara umum dalam masyarakat.

\section{Tempat Yesus Kristus dalam Wacana Kepemimpinan Masa Kini}

Pentingnya narasi tentang Yesus Kristus sebagai acuan bagi pengembangan kepemimpinan gereja masa kini tidak hanya disebabkan oleh keterkaitan gereja sendiri dengan Yesus Kristus, tetapi juga karena kepemimpinan bukanlah sekadar soal teknis organisasional yang dapat dijalankan semata-mata dengan kiat-kiat manajemen. Sesungguhnya kepemimpinan mengandung aspek spiritual yang membedakannya dari sekadar teknik manajemen. Reddy dan Kamesh mengamati bahwa kajian tentang kepemimpinan akhir-akhir ini mengalami pergeseran yang nyata dari penekanan terhadap aspek transformasional kepada suatu kesadaran bahwa kunci masalah kepemimpinan adalah relasi antara pemimpin dan

${ }^{4}$ Lihat: Verne H. Fletcher, Lihatlah Sang Manusia!: Suatu Pendekatan Pada Etika Kristen Dasar, lst ed. (Jakarta: BPK Gunung Mulia, 2007), 208-226. 
pengikut. $^{5}$ Menyadari tentang hal itu, Shah merumuskan definisi kepemimpinan sebagai "suatu perelasian spiritual antara pemimpin dan para pengikut di mana para pengikut, terinspirasi oleh pemimpin mereka, siap untuk menjalankan dengan penuh semangat kehendak dan upaya mereka untuk mencapai tujuan bersama." Shah menyayangkan diabaikannya aspek spiritual tersebut dalam pendekatan-pendekatan tentang kepemimpinan baik oleh kalangan akademia, para penulis populer, maupun para pemimpin sendiri. Pengabaian semacam itu mengakibatkan konsep-konsep kepemimpinan yang banyak diikuti justru gagal untuk menjangkau dimensi terdalam dari hakikat kepemimpinan itu sendiri. Lebih lanjut, Shah menegaskan bahwa gagasan tentang aspek spiritual dari kepemimpinan yang ia kemukakan itu bukanlah angan-angannya sendiri, melainkan bersumber pada data historis dan kajian interkultural masa kini. ${ }^{7}$ Menurut pengamatan Pruzan, minat untuk mengkaji aspek spiritualitas kepemimpinan sebenarnya menunjukkan peningkatan, namun hasil-hasil kajian itu cenderung tidak dapat dilanjutkan ke tahap operasional. Bagi Pruzan, memperlakukan spiritualitas sekadar sebagai objek kajian dan instrumen demi tujuan-tujuan pragmatis tidak akan menghasilkan apa-apa. Hanya jika spiritualitas dihayati sebagai pengalaman metafisik yang berharga, ia akan memberikan sumbangan bagi pengembangan diri pemimpin dan para pemangku kepentingannya. ${ }^{8}$

Pentingnya aspek spiritualitas dalam kepemimpinan juga dinyatakan oleh Breedt dan Niemandt yang secara spesifik menunjuk kepada spiritualitas yang bersumber pada relasi dengan Yesus Kristus sebagai "inkarnasi dari Allah yang relasional." Menurut Breedt dan Niemandt, jenis spiritualitas yang dibutuhkan dalam kepemimpinan masa kini adalah yang "dipimpin oleh Roh Kudus dan tergerak ke arah memberi makan orang yang lapar, menyembuhkan yang sakit, serta memberi harapan dan makna kehidupan bagi yang membutuhkan." Dengan menyebutkan peran Roh Kudus dan relasi Trinitaris, Breedt dan Niemandt menyatakan bahwa sebenarnya peran yang dimainkan Yesus

${ }^{5}$ Asi Vasudeva Reddy and A. V. S. Kamesh, "Integrating Servant Leadership and Ethical Leadership," in Ethical Leadership (Palgrave Macmillan, London, 2016), 108, https://doi.org/10.1057/978-1-137-60194-0_7.

${ }^{6}$ Javed Iqbal Shah, "Spiritual Aspect of Leadership Development: Moral Approach towards Understanding Leadership Phenomenon," The Dialogue 4, no. 3 (2009): 389.

${ }^{7}$ Shah, 369.

${ }^{8}$ Peter Pruzan, "Spiritual-Based Leadership: A Paradox of Pragmatism," in The Spiritual Dimension of Business Ethics and Sustainability Management, ed. Laszlo Zsolnai (Cham: Springer, 2015), 169. 
dalam pola kepemimpinannya bukan hanya sebagai pemimpin tetapi juga sebagai pengikut yang dipimpin oleh Roh untuk menjalankan misi Bapa. ${ }^{9}$

Dengan perkataan lain, aspek spiritualitas kepemimpinan menyiratkan bahwa pemimpin sejati bukanlah penguasa mutlak yang tidak menerima pimpinan dari pihak lain sehingga dapat menjalankan kekuasaan secara satu arah. Sebagaimana diyakini oleh Shah, pemimpin yang baik adalah juga pengikut yang baik. ${ }^{10}$ Maka, dari perspektif aspek spiritual kepemimpinan, signifikansi Yesus Kristus dalam konteks wacana kepemimpinan saat ini menjadi jelas. Dalam hal ini, kinerja kepemimpinan Yesus Kristus mengungkapkan sifat dan kedalaman relasi yang sepatutnya dijalin oleh seorang pemimpin baik dengan para pengikutnya maupun dengan pihak yang memimpinnya.

Dipahami seperti itu, relevansi kepemimpinan Yesus sebenarnya menembus batas ranah gereja dan lembaga Kristen. Upaya untuk menjadikan Yesus model kepemimpinan secara umum termasuk di dunia bisnis telah banyak dilakukan. Misalnya, Blanchard dan Hodges merumuskan langkah-langkah praktis kepemimpinan secara umum berdasarkan kepemimpinan Yesus. ${ }^{11}$ Selain itu, Michael Youssef telah berusaha menguraikan secara popular tentang kualitas, godaan, persoalan, dan masa depan kepemimpinan dengan mengacu pada gaya kepemimpinan Yesus. ${ }^{12}$ Sumbangan buku-buku popular semacam itu tentu layak dihargai, namun narasi Injil tentang Yesus mengandung lebih banyak aspek dan dimensi yang masih perlu digali untuk mengembangkan konsep kepemimpinan masa kini. Bagaimana pun upaya-upaya menyoroti relevansi kepemimpinan Yesus bagi konteks yang luas dapat dipahami sebagai tantangan bagi gereja agar tidak perlu terlalu cepat mengadopsi konsep kepemimpinan sekular dengan mengabaikan sumber-sumber teologisnya sendiri.

\section{Model-model Kepemimpinan Para Penguasa di Zaman Yesus}

Salah satu cara memahami kekhasan kepemimpinan Yesus adalah dengan membandingkannya dengan model-model kepemimpinan yang ditampilkan oleh para pemimpin lain di zaman-Nya. Kisah-kisah Injil mempersaksikan Yesus Kristus dengan ciri-ciri kepemimpinan yang

${ }^{9}$ J. J. Breedt and C. J. P. Niemandt, "Relational Leadership and the Missional Church," Verbum et Ecclesia 34, no. 1 (2013): 3, http://dx.doi.org/10.4102/ve.v34il.819.

${ }^{10}$ Javed Iqbal Shah, "Spiritual Aspect of Leadership Development: Moral Approach towards Understanding Leadership Phenomenon," 389.

${ }^{11}$ Ken Blanchard, Phil Hodges, Lead Like Jesus: Lessons from the Greatest Leadership Role Model of All Time (Nashville, Tennessee: Thomas Nelson, 2008).

${ }^{12}$ Michael Youssef, The Leadership Style of Jesus (Eugene, Oregon: Harvest House Publishers, 2013). 
menantang bagi para pemimpin resmi. Sedikitnya ada tiga pemimpin yang terusik dengan kehadiran Yesus yang menarik simpati orang banyak. Ketiga pemimpin itu, yaitu Pontius Pilatus, Herodes, dan Imam Besar Kayafas, terlibat dalam proses penghukuman atas diri Yesus. Sebenarnya, ketiga pemimpin itu juga mewakili tiga model kepemimpinan yang dapat dibandingkan dengan model kepemimpinan Yesus.

\section{Pontius Pilatus: Pejabat Pusat yang Ditempatkan di Daerah}

Pontius Pilatus dikenal sebagai wakil kaisar. Jabatan Pilatus adalah "procurator" yang kira-kira sama dengan gubernur jenderal dalam pemerintahan kolonial. Seorang pocurator memiliki kewenangan untuk memerintah wilayah tertentu di bawah koordinasi seorang "legaat" yang merupakan wakil kaisar dengan wewenang lebih besar dan memerintah wilayah yang berdekatan. Masa jabatan procurator terbatas dan setiap kali ia harus melaporkan kinerjanya kepada kaisar, baik secara langsung maupun melalui legaat. Pontius Pilatus menjabat selama sepuluh tahun. Jabatannya berakhir ketika legaat di Syria memerintahkan ia untuk menghadap kaisar pada tahun 36 AD untuk memberikan laporan pertanggungjawaban, tetapi situasinya sedang tidak menentu karena saat itu kaisar meninggal dunia. ${ }^{13}$

Tidak ada kesepakatan di antara para ahli sejarah tentang apakah Pontius Pilatus bersikap anti-semitik atau sekadar menghindari resiko dari keterlibatan dalam persoalan bangsa Yahudi. ${ }^{14}$ Namun cukup logis jika sebagai wakil kaisar Romawi, ia tidak dapat menyatu dengan rakyat yang di bawah kekuasaannya. Terdapat kesan yang kuat bahwa ia tidak memahami alam pikiran dan keyakinan bangsa Yahudi, sehingga tindakan-tindakannya banyak mendapat perlawanan. Salah satu kelompok yang melancarkan perlawanan keras adalah kaum Zelot. Pilatus menghadapi kelompok-kelompok keras masyarakat Yahudi dengan pendekatan konfrontatif dan kekerasan. ${ }^{15}$ Penyaliban adalah hukuman yang biasa dikenakan kepada "pemberontak" Zelot yang tertangkap. Dalam Lukas 13:1, disebutkan tindakan keji Pilatus terhadap orang-orang Galilea yang sedang menjalankan ibadah korban. Tindakan cuci tangan Pilatus dalam kasus penyaliban Yesus juga menunjukkan bahwa ia menempatkan diri di luar persoalan bangsa Yahudi, yang sebenarnya di bawah kekuasaan dan tanggungjawabnya. Yang menjadi

${ }^{13}$ Informasi tentang Pontius Pilatus ini diambil dari A. Sizoo Dari Dunia Perjanjian Baru (Jakarta: BPK Gunung Mulia, 1972).

${ }^{14}$ Brian C. McGing, "Pontius Pilate and the Sources," The Catholic Biblical Quarterly 53 (1991): 416-38.

${ }^{15}$ Mery Kolimon, "Empowerment: A New Generative Theme of Christian

Mission in a Globalized World," Exchange 40, no. 1 (January 1, 2011): 41,

https://doi.org/10.1163/157254311X550722. 
prioritasnya adalah menjalankan perintah dan kepentingan kaisar di wilayah jajahan itu. Jadi, yang penting baginya adalah bagaimana membuat bangsa Yahudi menjalankan perintah dan kemauan kaisar. Pemimpin semacam itu menganggap penilaian atasan sebagai ukuran keberhasilan.

\section{Herodes: Penguasa Lokal}

Herodes (Antipas) dalam cerita penyaliban Yesus disebut sebagai "raja seperempat negeri." Atas persetujuan Kaisar, ia mendapat sebagian dari wilayah yang sebelumnya dikuasai oleh ayahnya yang juga bernama Herodes, yaitu wilayah Galilea dan Perea. Jika si ayah bergelar raja, jabatan Herodes Antipas adalah "penghulu rakyat." Namun, baik raja maupun penghulu rakyat pada dasarnya memiliki kewenangan yang sama yaitu sebagai penguasa lokal yang diberi otonomi dalam bidang-bidang tertentu oleh kaisar, misalnya bidang hukum. Sebagai penguasa lokal, Herodes mempunyai kebebasan untuk menjalankan berbagai kebijakan dengan gayanya sendiri. Dalam beberapa hal, ia tidak harus mengikuti protokol kekaisaran. Kebebasan itu dimanfaatkan betul oleh Herodes untuk memperkaya diri dan membangun popularitas. Dibandingkan dengan Pilatus, Herodes lebih terlibat dalam kehidupan sehari-hari rakyat. Meskipun demikian, ia tetap menjaga jarak dengan rakyat. ${ }^{16}$ Lagipula ia tidak kalah kejam dari Pilatus. Kita mengenal cerita tentang bagaimana Herodes (Antipas) memenggal kepala Yohanes Pembaptis (Mrk. 6:14-29) atas permintaan anak tirinya, meskipun ia sendiri sebenarnya bersimpati terhadap pemberitaan Yohanes. Yesus menyebut Herodes sebagai "si serigala" (Luk. 13:32) karena kekejamananya. Maka Herodes juga dibenci oleh rakyat. Ia dapat terus memerintah dengan mengandalkan ancaman dan kekerasan. Sama seperti Pilatus, ia tidak punya kepedulian terhadap nasib rakyat. Ia hanya memikirkan kepentingan dirinya. Ia membebani rakyat dengan pajak yang tinggi untuk membiayai kepentingan politik dan birokrasi pemerintahannya. ${ }^{17}$ Bagi penguasa lokal semacam Herodes, rakyat adalah objek eksploitasi dan mainan untuk memuaskan seleranya.

\section{Imam besar Kayafas: Penguasa Sakral}

Imam besar adalah kepala para imam yang memimpin Bait Allah. Kewenangan imam besar mencakup bukan hanya bidang peribadatan dan keagamaan tetapi juga politik dan manajemen Bait Allah. Pada masa Yesus, kekuasaan imam besar dikontrol ketat oleh penguasa kolonial.

\footnotetext{
${ }^{16}$ A. Sizoo, Dari Dunia Perjanjian Baru, 35.

${ }^{17}$ Mery Kolimon, "Empowerment: A New Generative Theme of Christian Mission in a Globalized World," 41.
} 
Agar kedudukan mereka aman, para imam harus menerima kekuasaan penjajah sebagai kenyataan, meskipun secara ideologis mereka harus mengidealkan kemerdekaan bangsa Yahudi. Imam besar dan para imam di bawahnya mendasarkan kekuasaan mereka pada tradisi Yahudi dengan Taurat dan Bait Allah sebagai unsur-unsur penentunya. Karena itu, imam besar bersama imam-imam bawahannya cenderung menjadi benteng konservatisme agama. Berdasarkan tradisi, mereka mengklaim kedudukan mereka sakral dan karena itu berhak akan ketundukan dan penghormatan umat. Kesakralan itu diungkapkan melalui simbol-simbol yang terkesan agung dan berwibawa, termasuk pakaian keimaman dan ritus-ritus Bait Allah yang secara eksklusif hanya boleh dilakukan oleh mereka. Karena klaim kesakralan itu, para imam menjadi kelompok elite dari masyarakat, yang dalam kehidupan sehari-hari terpisah dari pergulatan nyata umat biasa.

Mengeksploitasi ketaatan rakyat yang lugu terhadap tradisi, imam besar dan imam-imam kepala kerap memainkan hukum agama dan aturan peribadatan demi kepentingan politis dan ekonomik mereka. Aksi teatrikal Yesus menjungkirbalikkan meja dan bangku pedagang di halaman Bait Allah (Mat. 21:12-17) dimaksudkan sebagai protes terhadap praktik kolusi yang dilakukan imam-imam Bait Allah dengan para pedagang. Jelas imam-imam merasa terusik dengan penampilan Yesus yang kritis terhadap tradisionalisme, karena itu mereka mengatur strategi untuk dapat menyingkirkannya. Pada akhirnya imam besar Kayafas yang menjatuhkan vonis mati terhadap Yesus dengan tuduhan penghujatan (Mat. 26:65-66). Itu menunjukkan bahwa kepemimpinan berbasiskan tradisi bisa menjadi sangat manipulatif dan kejam.

\section{Model Kepemimpinan Yesus}

Dibandingkan dengan ketiga penguasa di atas, status Yesus bukan apa-apa. Ia tidak memiliki jabatan formal apa pun walaupun orang sering memanggilnya "guru" (rabbi). Meskipun demikian, tidak dapat disangkal bahwa ia menjalankan fungsi kepemimpinan, baik dalam komunitas kecil murid-muridnya maupun dalam masyarakat luas yang sering disebut sebagai "orang banyak" dalam Injil. Dalam hal itu, Yesus mempersaksikan model kepemimpinan yang sama sekali berbeda dari yang dijalankan oleh para penguasa tersebut. Cara Yesus memimpin kelompok para murid kemudian dikenal sebagai model kepemimpinan pelayan (servant leadership). Secara simbolik, model kepemimpinan itu dilukiskan dalam peristiwa Perjamuan Malam yang terkenal itu, di mana Yesus melakukan pekerjaan yang lazimnya dilakukan oleh para budak, yaitu membasuh kaki murid-muridnya. Konsep kepemimpinan pelayan yang mulanya berinspirasi kepemimpinan Yesus sekarang dikembangkan di banyak 
perusahaan dunia, menjadi sebuah model kepemimpinan manajerial yang populer. Tentu kepemimpinan pelayan yang ditunjukkan Yesus bukanlah semata-mata soal kerendahan hati pemimpin. Beberapa aspek dalam kepemimpinan Yesus adalah: acuan mendasar pada Kerajaan Allah, pengenalan Allah sebagai Bapa, pengakuan yang kritis terhadap struktur kepemimpinan yang berpengaruh, dan pelayanan dengan hati yang tergerak oleh belas kasihan.

\section{Kepemimpinan yang Mengacu kepada Kerajaan Allah}

Kerajaan Allah atau Kerajaan Sorga (versi Injil Matius) adalah titik tolak dari kepemimpinan Yesus. Injil Markus dengan singkat menjelaskan inti pemberitaan Yesus yang dimulai segera setelah memenangi pencobaan di padang gurun: "Waktunya telah genap; Kerajaan Allah sudah dekat..." (Mark 1:15; juga Mat 4:17). Perlu diperhatikan bahwa 'proklamasi Kerajaan Allah' dilakukan Yesus bukan di Yerusalem yang merupakan pusat kekuasaan, tetapi di Galilea yang adalah lingkungan rakyat kecil.

Konsep Kerajaan Allah diwarisi dari tradisi Perjanjian Lama, ${ }^{18}$ berintikan pengakuan bahwa raja yang sebenarnya adalah Allah sendiri. Implikasinya, semua raja manusia bukanlah penguasa mutlak yang berhak menuntut ketundukan tanpa syarat. ${ }^{19}$ Karena itu, kekuasaan raja harus dikontrol dan dibatasi. Tindakan sewenang-wenang seorang raja, seperti Ahab terhadap Nabot atau Daud terhadap Uria, tidak boleh dibiarkan. Hanya Allah yang berhak akan ketaatan mutlak, sedangkan ketaatan terhadap semua raja manusia bersifat relatif: sepanjang raja menaati kehendak Allah dan menjalankan kekuasaannya dengan menjunjung tinggi keadilan, kesetiaan, dan tanggungjawab. Maka, teologi 'Kerajaan Allah' sebenarnya mendesakralisasi dan merelatifkan kekuasaankekuasaan manusia.

Salah satu kesalahpahaman terhadap teologi Kerajaan Allah adalah apa yang disebut sebagai model kepemimpinan 'teokrasi' yang menentang demokrasi. Di beberapa gereja, 'teokrasi' berarti pendeta utama memegang kekuasaan yang mutlak dan tidak boleh dikontrol oleh siapa pun, termasuk dalam hal pengelolaan keuangan. Teokrasi yang diklaim berdasar pada teologi Kerajaan Allah itu juga dijadikan landasan bagi praktik nepotisme di mana jabatan pendeta utama otomatis

${ }^{18}$ Stassen dan Gushee menunjuk secara spesifik pada teologi Kitab Yesaya sebagai kitab yang sering dikutip oleh Yesus. Konsep Kerajaan Allah cukup dominan dalam Kitab Yesaya. Penekankannya lebih pada tindakan Allah yang menyelamatkan dan membebaskan ketimbang pada hak Allah sendiri Glen H. Stassen and David P. Gushee, Etika Kerajaan: Mengikut Yesus Dalam Konteks Masa Kini (Surabaya: Momentum, 2008), 7-11. 
diturunkan kepada isteri, anak, atau menantu si pendeta. Di gereja lain, konsep teokrasi juga dijadikan alasan bagi Majelis Jemaat untuk menolak mempertanggungjawabkan kinerjanya kepada umat. Semua pemahaman itu melenceng jauh dari teologi Kerajaan Allah. Sesungguhnya, teologi Kerajaan Allah, yang mendesakralisasi dan merelatifkan kekuasaankekuasaan manusia, adalah dasar teologis yang jelas bagi demokrasi. Gereja yang menyadari tanggungjawab politiknya untuk ikut mengawal demokrasi dalam konteks kehidupan bangsa tidak boleh menolak demokrasi bagi konteks internalnya sendiri. Persepsi umat tentang kesakralan pejabat gereja perlu diperiksa kembali dalam terang teologi Kerajaan Allah yang membangun sikap kritis terhadap para pemegang kekuasaan.

\section{Allah adalah Bapa}

Menarik bahwa meskipun Yesus menjadikan 'Kerajaan Allah' sebagai acuan, Ia memperkenalkan Allah bukan pertama-tama sebagai Sang Raja, melainkan sebagai Bapa yang menyayangi anak-anaknya. Yesus membangun hubungan antara Tuhan dengan manusia bukan seperti hubungan rakyat dan raja yang berdasaran hukum dan formalisme, tetapi hubungan kekeluargaan yang mengutamakan pengampunan, penerimaan, dan keteladanan. Dasar hubungan itu bukanlah penguasaan-ketundukan melainkan kasih-komitmen. Dengan mengaitkan 'Kerajaan Allah' dengan kebapaan Allah, Yesus memaknai Kerajaan Allah bukan pertama-tama soal kekuasaan melainkan soal cinta kasih. Sayang hal ini tidak disadari dalam rumusan Pengakuan Iman Rasuli yang justru sebaliknya: memaknai kebapaan Allah sebagai soal kekuasaan, melalui pernyataan: “... Allah, Bapa yang mahakuasa..." Hasil penelusuran Feldmeier atas teologi kebapaan Allah dalam Perjanjian Baru menyimpulkan bahwa dalam kebapaan Allah terkandung sifat kemurahaan Allah yang diwujudkan dalam perkataan, tindakan, dan perilaku Yesus sendiri. ${ }^{20}$

Penyebutan Allah sebagai Bapa telah dipersoalkan oleh beberapa kalangan masa kini. Pertama, kelompok feminis tertentu menyatakan keberatan karena sebutan itu memberi kesan patriarki, bahwa Allah adalah laki-laki. Tentu tidak dapat disangkal bahwa penulis Alkitab hidup dalam masyarakat Yahudi masa lalu yang memang patriarki sehingga gambaran-gambaran mereka tidak bisa tidak mengandung sifat patriarki. Namun pembaca masa kini semestinya memiliki kebebasan untuk menafsirkan gambaran-gambaran semacam itu dari perspektif yang lebih sadar gender. Lagipula gambaran karakter Bapa dalam Injil sebenarnya mencakup juga sifat dan tindakan yang biasanya melekat pada diri

${ }^{20}$ Reinhard Feldmeier, "As Your Heavenly Father Is Perfect": The God of the Bible and Commandments in the Gospel," Interpretation 70, no. 4 (2016): 444. 
ibu, seperti memberi "makan secukupnya pada hari ini" sebagaimana diungkapkan dalam Doa Bapa Kami.

Sehubungan dengan pengalaman kekerasan dalam rumah tangga yang banyak dilakukan oleh ayah, banyak orang tidak dapat menghayati kebapaan sebagai soal kasih sayang. Bagi para korban kekerasan itu, kebapaan lebih dirasakan sebagai soal kesewenang-wenangan. Dalam hal ini perlu ditekankan bahwa kebapaan Allah dalam Injil harus dipahami dalam konteks narasi Injil tentang relasi ilahi Yesus. "Bapa" dalam Injil adalah Bapa dari Yesus Kristus yang menjadi Bapa semua orang percaya. Kebapaan Allah tidak dipahami dalam terang pengalaman masyarakat patriarki atau feodal. Sebaliknya, kebapaan Allah disajikan sebagai model bagi kebapaan manusia, dan dengan demikian kebapaan Allah mengoreksi kebapaan dalam tradisi masayarakat feodal yang mempunyai citra pelaku kekerasan. Dalam uraiannya tentang teologi Trinitas, Kathryn Tanner menyatakan bahwa relasi Yesus dengan Bapa tidak sama dengan relasi yang biasanya terjadi antara anak dan bapa yang bersifat hirarkis. Relasi Yesus dengan Bapa bukan seperti hamba dan tuan, melainkan relasi persahabatan dan kemitraan yang sempurna di mana kehendak yang satu pada akhirnya tampak pada yang lain. Ketaatan Yesus terhadap Bapa harus dipahami dalam terang relasi yang demikian. ${ }^{21}$

Jika kebapaan Allah hendak dipakai sebagai acuan bagi kepemimpinan gereja, persoalan-persoalan di atas seharusnya diperhitungkan. Sapaan bapa, romo atau semacamnya harus benar-benar bersumber pada karakter bapa dari Yesus Kristus sebagaimana dinarasikan dalam Injil. Pemanfaatan sebutan semacam itu untuk melanggengkan atau membangun budaya patriarki dalam gereja bertentangan dengan teologi kebapaan Allah dalam kepemimpinan Yesus.

\section{Pengakuan Kiritis terhadap Struktur}

Injil-injil menceritakan bahwa Yesus telah dianggap sebagai ancaman bagi penguasa politis sejak Ia di dalam kandungan. Lukas menulis tentang Maria, ibu Yesus, pada saat mendengar berita malaikat tentang kehamilannya oleh Roh Kudus. Saat itu Maria menaikkan nyanyian pujian yang isinya penuh cita-cita revolusioner, antara lain: "Ia menurunkan orang-orang berkuasa dari tahtanya dan meninggikan orang-orang rendah..." (Luk. 1:52). Matius menceritakan ketakutan Raja Herodes bahwa Yesus kelak akan menggulingkan dirinya sehingga ia memerintahkan pembunuhan bayi-bayi dengan identitas seperti Yesus (Mat. 2:16-18). Penyaliban Yesus sendiri dilatarbelakangi oleh parasaan terancam yang melanda para penguasa saat itu, khususnya para imam.

${ }^{21}$ Kathryn Tanner, Christ the Key (Cambridge, England: Cambridge University Press, 2009), 186, https://doi.org/10.1017/CBO9780511803499. 
Memang, meskipun Yesus tidak memiliki pasukan dan tidak memegang senjata, popularitasnya di kalangan rakyat kecil merupakan kekuatan politis yang bisa menjadi bola liar.

Namun Yesus sendiri sebenarnya tidak pernah punya niat untuk memberontak. Sikap politisnya dijelaskan ketika Ia menjawab pertanyaan tentang perlu tidaknya membayar pajak yang diajukan murid-muridNya. Dalam percakapan itu, Yesus menjawab: "berilah kepada kaisar apa yang wajib diberikan kepada kaisar, dan berilah kepada Allah apa yang wajib diberikan kepada Allah" (Luk. 20:25). Membayar pajak adalah bukti ketundukan kepada kaisar Romawi yang mengklaim dirinya ilahi. Jawaban Yesus mengakui sampai batas tertentu kekuasaan kaisar, namun sekaligus membedakan antara kaisar dan Allah. Artinya, ketundukan kepada kaisar tidak sama dengan ketundukan kepada Allah. Ketundukan kepada kaisar bersifat terbatas dan bersyarat, tidak boleh menjadi ketundukan mutlak yang membuta. Ketundukan yang mutlak adalah "yang wajib diberikan kepada Allah." Yesus mengajarkan sikap yang kritis terhadap struktur kekuasaan yang ada, bukan sikap apolitis bukan pula sikap feodal yang menjilat. Sikap kritis yang sama juga ditunjukkan terhadap struktur kekuasaan agama. Terhadap para ahli Taurat dan kaum Farisi, Yesus mengajarkan: “... turutilah dan lakukanlah segala sesuatu yang mereka ajarkan ..., tetapi janganlah kamu turuti perbuatanperbuatan mereka..." (Mat. 23:3). Itulah sebenarnya implikasi dari "Kerajaan Allah" yang Yesus ajarkan. Kerajaan Allah bukanlah struktur kekuasaan baru yang sedang diperjuangkan untuk menggantikan struktur yang ada, tetapi suatu referensi etis dan spiritual untuk menjalani kehidupan yang bertanggung jawab di dalam struktur kekuasaan yang ada. Teolog Calvinis, John Bolt, mengingatkan penolakan tegas Calvin terhadap pandangan bahwa Kerajaan Allah adalah alternatif bagi pemerintahan duniawi yang ada. Menurut Bolt, teologi Kerajaan Allah yang diusung oleh Yesus bahkan tidak dimaksudkan sebagai dasar bagi "perfeksionisme Kristen" yang mencari-cari kesalahan bagi setiap pemerintahan manusia. ${ }^{22}$ Sikap kritis Yesus memang tidak sama dengan perfeksionisme yang dimaksudkan oleh Bolt, tetapi teologi Kerajaan Allah mengandung implikasi sikap etis-politis yang mau tak mau memberikan penilaian moral terhadap praktik-praktik pengelolaan dan permainan kekuasaan.

Berbeda dengan Yesus yang berada di luar struktur kekuasaan, pemimpin gereja saat ini berada di dalam struktur institusi gereja. Pemimpin struktural punya kepentingan memperkuat struktur kekuasaan dan karena itu cenderung resisten terhadap sikap-sikap kritis.

${ }^{22}$ John Bolt, "The Imitation of Christ as Illumination for the Two Kingdoms Debate," Calvin Theological Journal 48, no. 1 (April 2013): 33. 
Jika mau memakai model kepemimpinan Yesus, para pemimpin gereja harus mulai dengan kasadaran bahwa konteks kepemimpinannya tidaklah terbatas pada ranah institusi gereja. Tantangan mendasar para pemimpin gereja adalah untuk terus menerus menyoroti struktur institusi gerejanya sendiri dengan lensa etika kepemimpinan Kerajaan Allah.

Kepemimpinan yang Digerakkan oleh Hati yang Berbelaskasihan

Jika bukan syahwat kekuasaan atau haus kehormatan atau kenikmatan fasilitas, apa yang dapat memotivasi seseorang untuk menjadi pemimpin? Injil-injil menggambarkan motivasi kepemimpinan Yesus jauh dari nafsu berkuasa, kehausan akan kehormatan, dan keinginan menikmati fasilitas. Baik pengajarannya maupun gaya hidupnya justru menunjukkan arah yang sebaliknya. Motivasi Yesus tidak terletak pada kepentingan dirinya sendiri, tetapi pada nasib orang banyak yang dipimpinnya. Matius menyatakan motivasi Yesus memimpin berdasar pada hatinya yang tergerak oleh belas kasihan. "Melihat orang banyak itu, tergeraklah hati Yesus oleh belas kasihan kepada mereka, karena mereka lelah dan terlantar, seperti domba yang tidak bergembala..." (Mat. 9:36). Yesus memimpin dengan hati. Karena itu, kepemimpinan-Nya berdampak bukan hanya pada kehidupan sosial masyarakat, tetapi juga pada dimensi yang paling personal dari orang-orang yang dipimpin-Nya. Penyembuhan orang sakit biasanya dianggap bukan urusan seorang pemimpin penguasa, tetapi dalam kepemimpinan Yesus penyembuhan justru dominan. Hanya pemimpin yang hatinya berbelaskasihan yang mengutamakan pembebasan dari masalah-masalah personal seperti sakit penyakit. Dalam cerita tentang penyembuhan yang terjadi di hari Sabat tampak bedanya pemimpin yang berhati belas kasihan dari pemimpin yang mengutamakan benda mati (aturan dan tradisi) ketimbang nasib manusia. Bagi pemimpin penguasa, perbaikan nasib orang hanyalah soal perubahan statistik.

Perkembangan gereja membutuhkan kejelasan aturan dan pelestarian tradisi agar tidak kehilangan arah dan menjadi terlalu pragmatis. Namun jika aturan dan tradisi kemudian dikeramatkan maka yang dipertaruhkan adalah pelayanan-pelayanan yang berbelaskasihan. Gereja yang tertib dan teratur berkat lengkapnya peraturan yang dibuat, serta estetik karena tekun menjaga tradisi, tentu baik. Namun keasyikan yang keterlaluan dalam membangun semua itu dapat mengalihkan gereja dari tugas utamanya yaitu menawarkan kelegaan bagi "semua yang letih lesu dan berbeban berat."

\section{Relevansi Model Kepemimpinan Pelayan Yesus Bagi Gereja Masa Kini}

Secara sosiologis maupun politis, gereja masa kini memiliki ciri-ciri yang berbeda dari orang banyak di zaman Yesus. Apakah model 
kepemimpinan pelayan yang dijalankan oleh Yesus masih relevan bagi gereja dan masyarakat masa kini? Keraguan terhadap relevansi kepemimpinan Yesus telah mendorong banyak pemimpin gereja untuk memakai model kepemimpinan sekular khususnya yang bersifat populer dan simplistik, dengan mengabaikan pelajaran penting yang dapat ditarik dari gambaran-gambaran kepemimpinan dalam Alkitab. ${ }^{23}$ Meskipun mengakui pentingnya teori-teori kepemimpinan sekular bagi konteks gereja, Parks menganggap penerapannya dalam konteks kepemimpinan gereja tidak dapat tidak dipertemukan dengan gagasan-gagasan yang terkandung di dalam Alkitab. 24

Bercermin pada model-model kepemimpinan zaman Yesus sebagaimana digambarkan dalam Injil, dapatlah dijelaskan praktikpraktik kepemimpinan dalam gereja masa kini di Indonesia. Ada gerejagereja yang mengkondisikan para pendeta bagaikan Pontius Pilatus: pejabat pusat yang ditempatkan di daerah. Komitmen utama para pendeta itu adalah pada pucuk pimpinan denominasi yang berwenang menempatkan, memutasi, memberhentikan, serta menilai kinerja mereka. Model seperti itu mendorong para pendeta untuk berlomba-lomba membuktikan bahwa diri mereka adalah "anak yang baik" sehingga layak diberi jabatan yang lebih tinggi atau tempat yang lebih bergengsi. Dengan demikian sukar bagi mereka untuk benar-benar menjadi bagian dari kehidupan umat. Biasanya mereka menjalankan pekerjaan mereka di jemaat sekadar untuk membuktikan kelayakan mereka. Fungsi mereka di jemaat lebih bersifat mengawasi ketimbang menggembalakan. Misi mereka lebih tertuju pada bagaimana memastikan bahwa kepentingan pimpinan denominasi diindahkan oleh jemaat.

Ada pula pendeta-pendeta yang berperilaku bagaikan penguasa lokal. Berbekal kewenangan yang melekat pada jabatan pendeta, mereka merasa berhak membentuk jemaat menurut keinginan dan selera mereka sendiri. Mereka menuntut jemaat untuk taat secara mutlak kepada mereka. Mereka mengklaim memegang hak tafsir tunggal atas ajaran, tradisi, maupun aturan yang berlaku di jemaat. Para pendeta penguasa lokal biasanya punya pesona (karisma) yang membuat jemaat bagaikan terhipnotis oleh kata-kata mereka. Sama seperti pejabat pusat, penguasa lokal juga biasanya tidak punya keprihatinan yang sejati terhadap nasib jemaat. Bagi mereka, jemaat hanyalah bagaikan mainan yang harus dapat memuaskan selera mereka sendiri.

Bagi pendeta-pendeta yang tidak cukup memesona, berlindung di balik kesakralan tradisi seringkali merupakan cara untuk mengamankan diri. Demi itu, ketakjuban dan ketakutan jemaat terhadap simbol-simbol

${ }^{23}$ Lewis A Parks, "Envy: A Study in Church Leadership from an Alternative,

Biblical Vision," Journal of Religious Leadership 2, no. 1 (2003): 2.

${ }^{24}$ Parks, 4. 
ritual seringkali dieksploitasi sedemikian rupa sehingga jiwa Injil dari simbol-simbol itu menjadi sukar dirasakan oleh jemaat. Para pendeta semacam itu membuat tradisi gereja yang seharusnya bersifat memerdekakan dan menggembirakan menjadi membelenggu dan menakutkan. Dengan demikian jemaat dibawa pada praktiknya ke arah penyembahan berhala. Sama seperti kedua model di atas, model pemimpin sakral juga sebenarnya tidak peduli terhadap nasib jemaat. Bagi mereka, jemaat adalah "untuk hari sabat," bukan sebaliknya.

Ketiga model kepemimpinan itu membentuk karakter jemaat yang transaksional, tidak kritis, dan feodal. Karakter-karakter itu bertentangan dengan demokrasi yang bersifat menghargai dan memberdayakan rakyat. Dalam praktik upaya rakyat Indonesia berdemokrasi, hambatan terbesar sebenarnya terletak pada karakter rakyat yang masih seperti itu. Contohnya adalah tradisi dukung-mendukung tokoh atau kelompok agama-politik yang dilakukan secara membabibuta. Selain itu, maraknya politik uang dalam praktik "serangan fajar" pada pemilihan umum dan pemilihan kepala daerah menunjukkan meningkatnya karakter transaksional dalam masyarakat. Semua itu sungguh berbahaya bagi kehidupan berbangsa dan bernegara.

Jika gereja ingin menyumbang bagi tegaknya demokrasi di negeri ini, gereja mesti mulai dengan pembentukan karakter jemaat yang merdeka dan peduli. Untuk membangun kepemimpinan semacam itu gereja sebenarnya tidak perlu meminjam model-model kepemimpinan dari sumber-sumber eksternal tetapi kembali kepada model kepemimpinan pelayan seperti yang diteladankan Yesus dan dipersaksikan dalam Injil.

\section{Kepustakaan}

Adeogun, Ebenezer Ola Olutosin. "The Kingdom of God and the Old Testament Theocracy." Ogbomoso Journal of Theology 12 (2006): 5986.

Blanchard, K., and Phil Hodges. Lead Like Jesus: Lessons from the Greatest Leadership Role Model of All Time. Thomas Nelson, 2008.

Bolt, John. "The Imitation of Christ as Illumination for the Two Kingdoms Debate." Calvin Theological Journal 48, no. 1 (April 2013): 6-34.

Breedt, J. J., and C. J. P. Niemandt. "Relational Leadership and the Missional Church." Verbum et Ecclesia 34, no. 1 (2013): art \$819. http://dx.doi.org/10.4102/ve.v34il.819.

Feldmeier, Reinhard. "As Your Heavenly Father Is Perfect": The God of the Bible and Commandments in the Gospel." Interpretation 70, no. 4 (2016): 431-444. 
Fletcher, Verne H. Lihatlah Sang Manusia!: Suatu Pendekatan Pada Etika Kristen Dasar. lst ed. Jakarta: BPK Gunung Mulia, 2007.

Frunza, Sandu. "Ethical Leadership, Religion and Personal Development in the Context of Global Crisis." Journal for the Study of Religions and Ideologies 16, no. 46 (2017): 3-16.

Hicks, Douglas A. "Ethical Diversity and the Leader's Religious Commitments." In The Quest for Moral Leaders: Essays on Leadership Ethics, edited by Joanne B. Ciulla. Cheltenham: Edward Elgar Pub, 2005.

Kolimon, Mery. "Empowerment: A New Generative Theme of Christian Mission in a Globalized World." Exchange 40, no. 1 (January 1, 2011): 35-56. https://doi.org/10.1163/157254311X550722.

McGing, Brian C. "Pontius Pilate and the Sources." The Catholic Biblical Quarterly 53 (1991): 416-438.

Parks, Lewis A. "Envy: A Study in Church Leadership from an Alternative, Biblical Vision." Journal of Religious Leadership 2, no. 1 (2003): 87-110.

Pruzan, Peter. "Spiritual-Based Leadership: A Paradox of Pragmatism." In The Spiritual Dimension of Business Ethics and Sustainabilty Management, edited by Laszlo Zsolnai. Cham: Springer, 2015.

Reddy, Asi Vasudeva, and A. V. S. Kamesh. "Integrating Servant Leadership and Ethical Leadership.” In Ethical Leadership, 107-24. Palgrave Macmillan, London, 2016. https://doi.org/10.1057/978-1137-60194-0_7.

Shah, Javed Iqbal. "Spiritual Aspect of Leadership Development: Moral Approach towards Understanding Leadership Phenomenon." The Dialogue 4, no. 3 (2009): 387-408.

Sizoo, A. Dari Dunia Perjanjian Baru. Jakarta: BPK Gunung Mulia, 1972. Stassen, Glen H., and David P. Gushee. Etika Kerajaan: Mengikut Yesus Dalam Konteks Masa Kini. Surabaya: Momentum, 2008.

Tanner, Kathryn. Christ the Key. Cambridge Core, 2009. https://doi.org/10.1017/CBO9780511803499.

Youssef, Michael. The Leadership Style of Jesus. Harvest House Publishers, 2013.

Zubaedi. "The Use of Religious Issues in Local Head Election (Pilkada): A Lesson from Bengkulu." In Filsafat, Etika, Dan Kearifan Lokal Untuk Konstruksi Moral Kebangsaan, edited by Siti Syamsiatun and Nihayatul Wafiroh. Geneva: Globethics.net, 2013. 